\title{
Honour and debt release in the parable of the Unmerciful Servant (Mt 18:23-33): A social-scientific and realistic reading
}

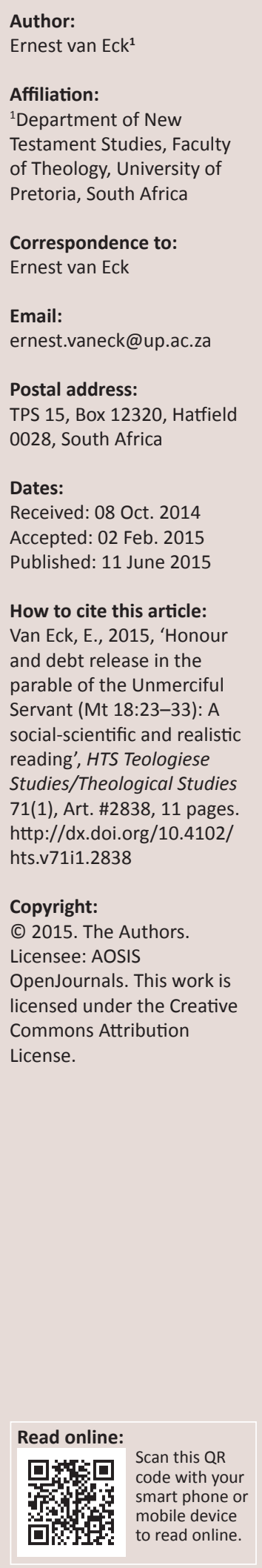

This article presents a social-scientific and realistic reading of the parable of the Unmerciful Servant. The parables of Jesus are realistic stories about everyday events in 1st-century Palestine that evoke specific social realia and practices known to its first hearers. As recent studies on the parables have shown, papyri from early Roman Egypt provide detailed information on the implied social realities and practices assumed in the parables. In reading the parable through the lens of patronage and clientism and against the background of the relationship between royal ideology and debt release attested in documented papyri, it is argued that the parable suggests that in the basileia of God debt should be released in terms of general reciprocity, emulating the way in which patrons release debt for the sake of honour.

\section{Introduction}

The history of the interpretation of the Unmerciful Servant indicates that, in spite of different exegetical approaches, different points of view on the integrity of the parable, and differences of opinion regarding the reference to the king in Matthew 18:23 as metaphorically referring to God or not, almost all interpretations of the parable echo Origin's 3rd-century allegorical-theological interpretation of the parable. According to these readings, the debt referred to in the parable is either a sin against God or fellow human beings, and because God (the king) forgives abundantly, the same forgiveness should be extended to other human beings.

To avoid this anachronistic reading of the parable, cultural awareness of the 'other' and cultural and theological self-awareness is needed. For such a reading, we have to assemble solid ancient comparanda on the practices and social realities which the parable presupposes. Several recent studies on Christian ancient texts (like the parables) have indicated that papyri from early Roman Egypt, sometimes as our only source, can provide some of this needed information on the social realities and practices assumed in the parables.

In this article, the Unmerciful Servant is read against the background of attested royal ideology on debt release in documented papyri, combined with a social-scientific reading that focuses on patronage and clientism and honour and shame. It is suggested that in the parable Jesus advocates that in the basileia of God debt should be released in terms of general reciprocity, emulating the way in which patrons release debt for the sake of honour.

\section{History of interpretation}

The earliest interpretations of the parable of the Unmerciful Servant are the allegorical interpretations of Matthew, the Church Fathers and later interpretations from the medieval period. ${ }^{1}$ Not all the Church Fathers, though, interpreted the parable from an allegorical perspective. Origen (182-254) combined an allegorical and theological interpretation of the parable; in interpreting the debt of the two servants as sin against God and fellow humans, he read the parable as a moral teaching of Jesus on forgiveness, namely that forgiveness received from God should lead to forgiveness extended to fellow humans. ${ }^{2}$

\footnotetext{
1.In Augustine's interpretation of the parable the debt of the two servants is seen as sins against the Law, the debtor's wife and his children represent excessive desire and works of the Law, and the greater and lesser debtors represent the Jews and Gentiles (see Wailes 1987:132-137), whilst the forgiveness of the king refers to baptism which gives every sinner a new beginning (Sermon XXXII). According to Chrysostom (Homily LXII) the contrast between the ten thousand talents and hundred denarii refers to sins against According to Chrysostom (Homily LX (673-735) interpretation, the Unmerciful Servant represents the Jews who, although they were God and sins aganterion, the Unmerciful Servant represents the Jews who, although they were subsions. Some modern scholars also tend to read the parable allegorically. Drury (1985.920, the vast debt of the Unmerciful Servant as a reference to the great evil that resides in man when compared to God's holiness.

2.Origen ends his interpretation of the parable with the following summary: ' $[A]$ ll of us who have obtained the forgiveness of our own sins, and have not forgiven our brethren, are taught at once that we shall suffer the lot of him who was forgiven but did not forgive his
} fellow-servant' (Origen, Commentary on Matthew XIV, 13). 
When one looks at the history of the interpretation of the parable, Origen's allegorical-theological interpretation has become the standard interpretation of the Unmerciful Servant; the essence of his interpretation can be traced in interpretations of the parable through the medieval period, up to the most current interpretations being offered. In Aquinas (1225-1274) (in Davie 2007) and Maldonatus's (1533-1583) interpretations, for example, Origen's influence is clear. In Aquinas's view, the focus of the parable is the mercy of God, the nature of ingratitude and the judgement of the ungrateful (see Kissinger 1979:43), whilst John Maldonatus drew from the parable the 'theological truth' that God will not forgive us unless we forgive one another (see Davie 2007:103).

As in the cases of Aquinas and Maldonatus, almost all modern interpretations of the parable concur with Origen's allegorical-theological interpretation, either confirming his interpretation, or highlighting aspects thereof. Almost all scholars who interpret the parable in its Matthean context link the king (Mt 18:23) with Matthew 18:35 ('So also my heavenly Father will do to every one of you, if you do not forgive your brother from your heart' [RSV]), and as result see behind the king a metaphor for God. ${ }^{3}$ This 'obvious' link between Matthew 18:23 and 35 is then used as key to interpret the parable as a description of God's forgiveness, mercy, compassion or judgement, and/or a moral teaching on the effect these attributes of God should have on the one who has received forgiveness. Interestingly, scholars who read the parable in its Matthean context with the premise that Matthew 18:35 is a Matthean addition, also see the king as a metaphoric reference to God and read the parable in the same way. ${ }^{4}$ Moreover, scholars who explicitly read the parable as a parable of Jesus - thus not in its Matthean context - also come to the same conclusion as Origen. The fact that some of these scholars argue whether Matthew 18:35 was part of the original parable or not $^{6}$ does not make any difference to their respective interpretations. This is also the case when these scholars equate the king in the parable metaphorically with God or not. ${ }^{7}$ In nuce, in spite of these different approaches, different opinions on the inclusion or exclusion of Matthew 18:35, and whether the king metaphorically refers to God or

3.See, for example, Boucher (1981:116-118), Inrig (1991:63-78), Brouwer (1946:5179), Stiller (2005:44-55), Kistemaker (1980:65-70), Manson (1949:213-215), Reid (2001:131-142), Groenewald (1973:125-133), Capon (1988:43), Hultgren (2000:20-33), Hunter (1971:70-72), Kendall (2006:158-167), Morgan (1953:8993), Borg (2006:177), Via (1967:137-144), Weder (1984:177-184), Oesterley (1936:95) (2006:177), Via (1967.137-144), Weder (1984:177-184), Oesterley its Matthean context, Schippers (1962:133-138) and Ford (1997:47-64), do not consider the king as a metaphoric reference to God.

4.Scholars who argue that Matthew 18:35 is a Matthean addition, but still see the king in the parable (Mt 18:23) as a metaphor for God, are Via (1967:137-144), Oesterley (1936:95), Donahue (1988:72-79) and Weder (1984:177-184)

5.See inter alia Jeremias (1972:210-212), Boice (1983:179-187), Blomberg (2004:7182, 2012:314-232), Wenham (1989:151-155), Lockyer (1963:217-219), Dwigh (1982:61-63), Snodgrass (2008:61-76) and Barclay (1970:86-91).

6.See Lambrecht (1992:53-68), Perrin (1967:125), Funk, Hoover and Jesus Seminar (1993:218-219), Crossan (1973:101-109) and Linnemann (1980:105-113).

7.Scholars who interpret the parable as stemming from Jesus, and argue that Jesus intended the king to be a metaphoric reference to God are Jeremias (1972:210212), Boice (1983:179-187), Blomberg (2004:71-82; 2012:314-232), Snodgrass (2008:61-76), Wenham (1989:151-155), Lockyer (1963:217-219), Lambrech (1992.53-68), Dwight (1982:61-63), Linnemann (1980:105-113) and Barclay (1970:86-91). For scholars who read the parable from the same perspective, but do not see the king as a metaphorical reference to God, see Perrin (1967:125), Funk et al. (1993:218-219) and Crossan (1973:101-109). not - almost all interpretations point in the same direction, echoing that of Origen.

An overview of interpretations of the Unmerciful Servant offered by parable scholars substantiates this conclusion. The following examples will suffice: The parable teaches that God's forgiveness is a gift that must be shared (Boucher 1981:115-116; Via 1967:139, 142-143); that forgiving must take place on numerous occasions (Inrig 1991:46); that the parable focuses on the quality of forgiveness (Brouwer 1946:162); that God's forgiveness can only be received if forgiveness is shown to others (Barclay 1970:88); or that forgiveness must be given without measure (Capon 1988:43). Other themes identified are the coming judgement of God when one does not forgive (Boice 1983:186; Blomberg 2004:72-73; 2012:319; Jeremias 1972:213; Kendall 2006:159); the compassion (Borg 2006:177; Morgan 1953:92) or the mercy of God (Weder 1984:180); the limitless nature of divine forgiveness (Linnemann 1966:111-113; Oesterley 1936:95; Schippers 1962:138); that one will lose authentic life if one does not forgive like God does (Dietzfelbinger 1972:437451); or that forgiveness among humans is a sign of God's presence (Schottroff 2006:201). Finally, the most common interpretation offered is that forgiveness received must turn into forgiveness given (Crossan 1973:104; Donahue 1988:7677; Dwight 1982:63; Ford 1997:47; Groenewald 1973:127; Hultgren 2000:23; Hunter 1960:71; 1971:71; Kistemaker 1980:67; Lambrecht 1992:63; Lockyer 1963:217; Manson 1949:213; Reid 2001:140; Stiller 2005:49; Snodgrass 2008:61; Wenham 1989:153). ${ }^{8}$

All these interpretations echo that of Origen. The debt of the Unmerciful Servant is seen as sin against God, and the debt of the fellow slave as sin against a fellow human being. Because the merciful and compassionate God forgives, those who received forgiveness should also forgive, otherwise judgement awaits. Not only are these interpretations allegorical-theological, but also anachronistic. To this we now turn.

\section{The parables and realism}

An anachronistic interpretation of the parables entails an interpretation that reads 'into the text information from some present social context rather than comprehending the text in accord with its own contemporary social and cultural scripts' (Elliott 1993:11). Cultural awareness of the 'other' however, is only half of the problem when it comes to cross-cultural communication. Cultural self-awareness is also necessary to understand why we frequently project ourselves onto the language and thinking of others (Rohrbaugh 2006:563). This holds true for our theological awareness as well. Because sin, from a theological perspective, is seen by many as a debt to God or fellow humans, this understanding of debt

8. Linked to this interpretation are the interpretations of Perrin (1967:125) and Funk et al. (1993:219). According to Perrin, the parable challenges its hearers to forgive because the new reality of God's reign has arrived in Jesus, whilst for Funk et al. Jesus told the parable to invite the listener to choose the appropriate mode of behaviour. The interpretation of Perrin and Funk et al. thus only differs from the behaviour. The interpretation of Perrin and Funk et al. thus only differs from the
'standard' reading in the sense that forgiveness received must turn into forgiveness given because in Jesus the kingdom has arrived as a new reality. 
is projected onto the parable; the king is seen as God, and the interpretation can only go in one direction. To read the parable from this perspective is to depict a Jesus that made theological statements. Jesus, on the contrary, had no doctrine of God, made no theological statements, and never used abstract language. ${ }^{9}$

The parables, as put by Dodd (1961:10), are realistic narratives about everyday events in 1st-century Palestine (see also Zimmermann 2007:25;10 Kloppenborg 2011:325). The parables of Jesus are stories about dinner parties, prodigal sons, seed being sown, labourers in a vineyard and persons accruing debt. As suggested by Kloppenborg (2014b:490), in some cases 'a vineyard or a shepherd in a parable of Jesus is just a vineyard or a shepherd.' And debt is simply debt, as in the case of the parable under discussion. This is also the point of view of Herzog (1994:135-136): The narrative repertoires (social scenarios) depicted in the parables are not incidental, irrelevant or unrelated to social reality, but 'are grounded in the story-teller's social, political, and cultural milieu.' Hence, the social settings of the parables are windows to their meanings (Herzog 1989:135-136; see also Scott 1989:270).

Several studies on the parables by Kloppenborg have indicated that papyri from early Roman Egypt provide detailed information on social realities in the parables (see, inter alia, Kloppenborg 2006; 2011:323-351; 2014a:287-306; 2014b:491-511, 556-576, 577-599). In the interpretation of the parables, Kloppenborg (2014b:490-491) argues, that the social realia invoked in the parables cannot be neglected, 'and we ought to get clear on the most basic meanings of the images in question before moving to abstract, symbolic or allegorical meanings' (Kloppenborg 2014b:490). As put by Kloppenborg (2014b):

We have to assemble solid ancient comparanda on the practices and social realities which the sayings of Jesus and the parables presuppose. For such a project, documentary papyri are usually our most plentiful, and sometimes only, resource. $(2)^{11}$ (see also Bazzana 2011:511, 517)

In interpreting the parables one should assume that the first audiences of Jesus' parables, most probably the peasantry in Galilee, already had cultural competence in these ancient practices, and had native (emic) knowledge of the social realia

9. See in this regard Funk (2007:90), who states that the parables of Jesus 'are not stories of God - they are stories about God's estate' $\mathrm{Or}$, in the words of Herzog stories of God - they are stories about God's estate.' Or, in the words of Herzo (1994:3): '[The parables were not earthly stories with heavenly meanings, but earthly stories with heavy meanings. The following quote from Kloppenbor (2014b:490) should also be taken note of: Few nowadays would defend the preposition that Jesus was an allegorist, speaking in one discursive realm but in fact intending to evoke other discursive realms, for example, salvation history or the care of the soul.

10.A parable is 'a short narrative text, which refers in its narrated world to a known reality but which by means of implicit or explicit signals makes it clear that the significance of what is narrated is to be distinguished from the wording of the text. In its appeal it requires a reader to accomplish a metaphoric transfer of meaning guided by contextual information' (Zimmermann 2007:25; translation from Kloppenborg 2014a:287).

11.The Graeco-Egyptian papyri, and a few papyri preserved from the 'Arava, are contemporary with papyri, and a few papyri preserved from the 'Arava, are strata and processes. With 'due allowance made for legal and cultural differences between Egypt and Palestine' these papyri 'can provide useful comparative data for understanding the realia which the parables presuppose' (Kloppenborg 2014a:289). referred to in the parables. It is therefore 'hardly a surprise that the Synoptics do not bother to explain or elaborate on any of these matters' (Kloppenborg 2014b:2). ${ }^{12}$ When interpreting the parables, we thus run the risk of serious anachronism if these practises and realia are not taken into consideration (Kloppenborg 2014b:2) - as the history of the interpretation of the Unmerciful Servant described above illustrates.

In an effort to avoid anachronistic interpretations of identified social realia, a culture-sensitive reading is needed, and socialscientific criticism offers that. Social-scientific criticism approaches texts from the premise that texts always are the products of specific social systems; therefore, to understand a text, attention must first be given to the social system that produced the text. Social-scientific criticism has developed several theories to interpret specific identified social realia in biblical texts. Two of these theories, namely patronage and clientism and honour and shame, will be employed in the reading of the parable below.

\section{Integrity}

Matthew 18:23-35 is the only extant version of the parable of the Unmerciful Servant. There is a general consensus among Matthean scholars that Matthew has structured his narrative of Jesus around five discourses (Mt 5:1-7:27; 10:142; 13:1-52; 18:1-35; 24:1-25). All these discourses conclude with an eschatological warning (see Mt 7:15-27; 10:32-42; 13:49-50; 18:35; 25:31-46), whereafter Matthew uses a familiar (similar) formula to link the discourses to the next section of his narrative (see Mt 7:28; 11:1; 13:53; 19:1; 26:1). Matthew has placed the Unmerciful Servant at the end of his fourth discourse, ending the parable and discourse with an eschatological warning in Matthew 18:35. This already gives an indication that Matthew 18:35 most probably is a Matthean addition to an earlier version of the parable.

Matthew 18 is Matthew's so-called narrative on 'church order', and consists of five smaller narratives. Matthew 18:1-10 deals with the question of who is the greatest in the kingdom, with Jesus' answer that the greatest ones in the kingdom are those who are as humble as a child (Mt 18:4);

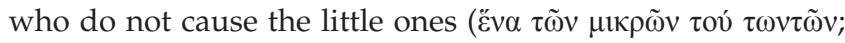
Mt 18:6) to sin; and do not despise the little ones (غ่vò $\varsigma \tilde{\omega} v$

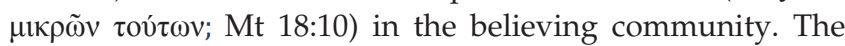
second micronarrative of the discourse is the parable of the Lost Sheep (Mt 18:12-14), which Matthew allegorised to fit

12.The reason for this 'lack' of explanation is because the texts we have of the parables are products of a high context society. Elliott (1993:11) explains this feature of the parables as follows: ' $[T]$ he New Testament ... consists of documents written in what anthropologists call a "high context" society where the communicators presume a broadly shared acquaintance with and knowledge of the social context of matters referred to in conversation or writing. Accordingly, it is presumed in such societies that contemporary readers will be able to "fill in the gaps" and "read between the lines"' (Elliott 1993:11). According to Rohrbaugh (2006:567), the main problem for mes (Ellion modern readers of the parables therefore is 'that we do not know what we do not know.' Rohrbaugh (2006:567) continues: 'The current consensus view of parable is that they are something like open-ended, extended metaphors that force the reader to arrive at conclusions of his/her own. That may or may not be accurate but of course the missing piece is knowledge of the context. If we knew all about the setting in which these stories were first told perhaps we would get the point in the fashion a high context person would expect. But lacking it ... we arrive at conclusions that often bear no relation to an ancient context whatsoever.' 
as an example of how the believers in the community should take care of the little ones. This Matthew has done with the

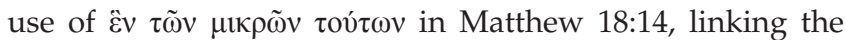
parable with Matthew 18:6 and 10. The third micronarrative (Mt 18:15-20) has the focus of how a transgression of a community member should be dealt with. The fourth micronarrative (Mt 18:21-22) consists of Peter's question and Jesus' answer on the limits of forgiveness, and then follows the parable of the Unmerciful Servant (Mt 18:23-35).

Although some scholars argue that Matthew 18:21-22 should be seen as part of the parable (e.g. Brouwer 1946:162; Lambrecht 1992:54; Oesterley 1936:93-94), the parable has no reference to unlimited forgiveness mentioned in Matthew $18: 22$, and the king in the parable surely does not live up to Jesus' saying on repeated and unlimited forgiveness. ${ }^{13}$ Moreover, when the king in the parable is seen as a metaphor for God (based on Mt 18:35), the picture of God painted in the parable is quite unflattering in that God is pictured as 'a vindictive person whose mercies are dependent on human behavior' (Funk et al. 1993:218). The parable clearly does not fit its Matthean context (following Mt 18:21-22), which means that Matthew attached the parable of the Unmerciful Servant (stemming from $\mathrm{M}$ ) to the end of his discourse in Matthew 18 to further elaborate on forgiveness in the community. ${ }^{14}$

Matthew has redactionally edited Matthew 8:23 ( $\Delta$ ì̀ $\tau$ 七õ $\tau$ o

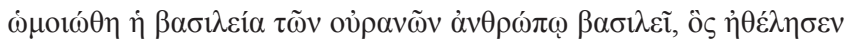

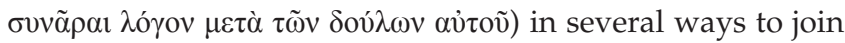
it with Matthew 18:21-22, enabling him to incorporate the version of the parable received from $\mathrm{M}$ into his discourse in Matthew 18 in a way to serve his own (allegorical) purposes (see Blomberg 2012:315; Boucher 1981:117; Crossan 1973:105; Herzog 1994:132-134; Jeremias 1972:210; Linnemann

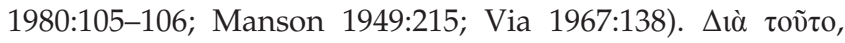

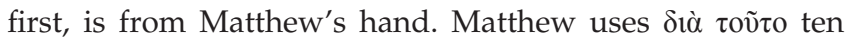
times in his Gospel as an introductory formula, twice as an introduction to a parable (Mt 13:52; 18:23) and eight times to introduce a conclusion made by the Matthean Jesus (see Mt $6: 25 ; 12: 27 ; 12: 31 ; 13: 13 ; 14: 2 ; 21: 43 ; 23: 34 ; 24: 24)$. Of these

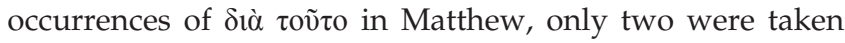
over from Mark (Mk 6:14; 11:49; par. resp. Mt 14:2; 23:34), and one is paralleled in Luke (Lk 11:19; par. Mt 12:27).

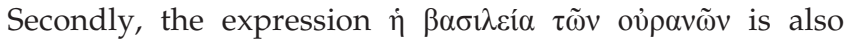
typically Matthean. Only Matthew uses this expression, occurring 25 times in the Gospel (contra Scott 1989:269, n. 6). Of these 25 occurrences, Matthew uses $\dot{\eta} \beta \alpha \sigma i \lambda \varepsilon i ́ \alpha \tau \tilde{\omega} v$ ov̉ $\rho \alpha \tilde{\omega} v$ 11 times in combination with either $\dot{\mu} \mu \mathrm{o} \omega \dot{\theta} \eta$ (Mt 13:24; 18:23;

13.This, of course, only being the case when Matthew 18:24-35 is seen as part of the parable.

14.Some interpreters see no clash between Matthew 18:21-22 and the parable, arguing that Matthew 18:21-22 deals with the quantity of forgiveness, while the parable deals with its quality (see Donahue 1988:73; Lambrecht 1992:56). Schottroff (2006:200-201) also sees no clash between Matthew 18:21-22 and the parable, arguing that the readers of the parable would not have equated the king in the parable with God since it would have been seen as blasphemy in the eyes of the Jewish tradition. See the history of the interpretation of this aspect of Matthew 18 in Luz (2012:346-348), and a discussion of the clash between Matthew 18:21-22 and 23-35 in Dodd (1961:33), Hultgren (2000:30), Snodgras (2008:67, 71), Herzog (1994:132), Crossan (1973:103, 105-106) and Davies and Allison (1997:791-794)

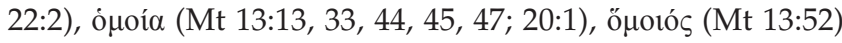

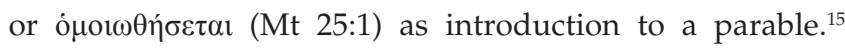
This introductory formula of Matthew is only paralleled in Luke 13:18 (the parable of the Mustard Seed; par. Mt 13:24) and Luke 13:20 (the parable of the Leaven; par. Mt 13:33), in both cases replacing Matthew's introductory formulae

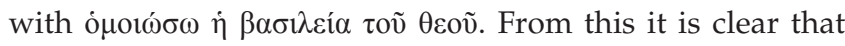
Matthew's use of $\dot{\eta} \beta \alpha \sigma \iota \lambda \varepsilon i ́ \alpha \tau \tilde{\omega} v$ oủ $\rho \alpha v \tilde{\omega} v$ in combination with

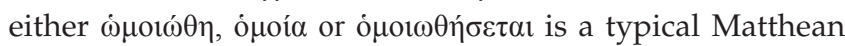
addition used to introduce the parables in the Gospel. As

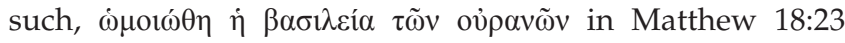
most probably was not part of the version of the Unmerciful Servant used by Matthew, and should be considered as a Matthean addition.

Thirdly, Matthew also most probably added öv $\theta \rho \omega \pi$ ó $\varsigma$ in Matthew 18:23. Part of the Matthean style is to describe persons with the use of two nouns ('double designation'):

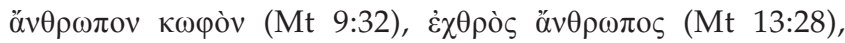

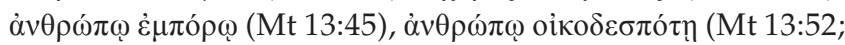
20:1), and $\dot{\alpha} v \theta \rho \omega ́ \pi \omega \beta \alpha \sigma \imath \lambda \varepsilon \tilde{\imath}$ (Mt 22:2). That it is a tendency of Matthew to always make use of this double designation

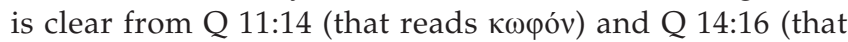

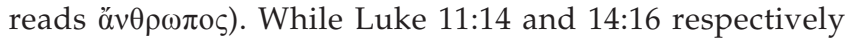

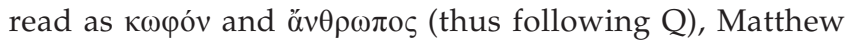

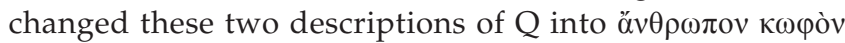
(Mt 9:32) and $\dot{\alpha} v \theta \rho \omega ́ \pi \omega \beta \alpha \sigma \imath \lambda \varepsilon \tilde{\imath}$ (Mt 22:2); adding $\alpha \dot{v} \theta \rho \omega \pi \mathrm{ov}$ in Matthew 9:32 and $\beta \alpha \sigma 1 \lambda \varepsilon \tilde{\imath}$ in Matthew 22:2. Because of Matthew's consistent use of this 'double designation', based on his redactional changes of Q 11:14 and 14:16, there is thus a reasonable possibility that Matthew changed $\beta \alpha \sigma i \lambda \varepsilon \tilde{i}$ in $\mathrm{M}$ to $\alpha \dot{\alpha} \theta \rho \omega \dot{\pi} \omega \beta \alpha \sigma i \lambda \varepsilon \tilde{i}$. In light of the above, Matthew thus most probably changed an earlier

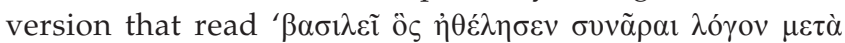

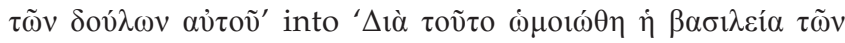

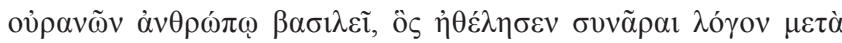

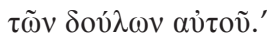

A further Matthean redaction of the parable is the use of $\mu v \rho i ́ \omega v \tau \alpha \lambda \alpha ́ v \tau \omega v$ in Matthew 18:24. Matthew's use of $\mu \nu \rho i ́ \omega v$ $\tau \alpha \lambda \alpha^{\prime} \nu \tau \omega \nu$ is interpreted differently by interpreters of the parable. Perkins (1981:124) and Linnemann (1980:108), for example, argue that the sum is not exceptional, since it would have reminded the Jewish audience of the parable of the riches of Egyptian and Persians kings that they had heard about from distant times and lands. Snodgrass (2008:68) sees the sum as pseudo-realistic, but 'not unthinkable'. ${ }^{16}$ Almost all other interpreters of the parable see the number

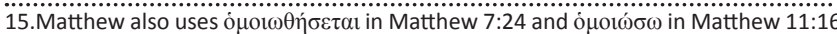

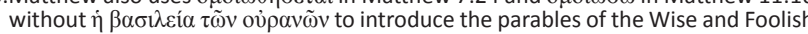
Builders (Mt 7:24-27; par. Lk 6:47-49), and the parable of the Children at the Marketplace (Mt 11:16-19; par. Lk 7:31-35). Luke, in both these cases, follows

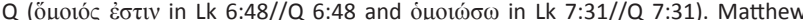

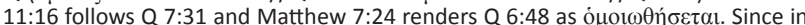
the case of $Q 6: 48$ both the readings of Matthew 7:24 and Luke 6:48 are possible renderings of $Q 6: 48$ (see Robinson et al 2000:98-99), it seems that Matthew,

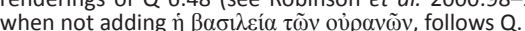

16.As evidence he sites Esther 3:9 (Haman's promise to pay ten thousand talents into the treasury), Josephus (Ant. 14.78; Pompey exacting ten thousand talents from the Jews after his siege of Jerusalem in $63 \mathrm{BCE}$ ), and Josephus (Ant. 12.175-176; the Jews after his siege of Jerusalem in $63 \mathrm{BCE}$ ), and Josephus (Ant. 12.175-176,
Joseph, a tax farmer, offering Ptolemy to collect sixteen thousand talents). For further examples to substantiate his point of view, see Snodgrass (2008:604, n. 26) 
as unrealistic, ${ }^{17}$ in most cases referring to Josephus who indicates that Herod the Great's annual income at the time of his death in $4 \mathrm{BCE}$ amounted only to nine hundred talents (see Josephus, Ant. 17.318-320), some adding that Josephus was known for inflating numbers (Herzog 1994:143). To address the unrealistic number of Matthew, several scholars have suggested a correction to Matthew's use of $\mu v \rho i ́ v \tau \tau \alpha \lambda \alpha ́ v \tau \omega v$. De Boer's (1988:228) suggestion is that the version used by Matthew most probably read denarii, and was changed by Matthew into talents. ${ }^{18}$ Matthew's purpose of this change was to align the high number with $\beta \alpha \sigma \lambda \lambda \varepsilon \tilde{i}$ in Matthew 18:23, impelling the hearer of the parable to interpret the parable allegorically and to understand the king as a figure for God. In Lambrecht's (1992:59-60) view, De Boer's suggestion is most probably correct for two reasons. Firstly, the Unmerciful Servant states in Matthew 18:26 that, if the master has patience with him, he would be able to pay back everything he owes. If the sum owed by the servant was

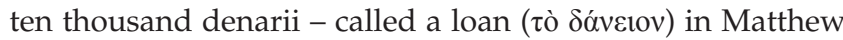
18:27 - it indeed was repayable. Secondly, Matthew, in the parable of the Talents (Mt 25:25:14-30) - as in the Unmerciful Servant - changed the original $\dot{\eta} \mu v \tilde{\alpha}(\operatorname{Lk} 19: 16,18,20)$ of the Q-parable into $\tau \dot{\alpha} \lambda \alpha \nu \tau \alpha$ (see Mt 25:15, 16, 20, 22, 28).

Finally, Matthew 18:35 was also most probably added to the version of the parable known by Matthew. The expression

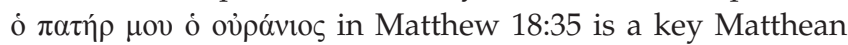
phrase (see Mt 5:48; 6:14, 26, 32; 15:13; 18:35; 23:9). As indicated above, Matthew 18:35 is the conclusion to the entire discourse in Matthew 18, and thus the possibility exists that it was not intended by Matthew to be part of the parable (see Crossan 1973:103; Herzog 1994:133; Via 1967:139). However, if it is part of the parable, Matthew most probably added it to the M-version as a moral attachment to give the parable an explicit meaning (see Blomberg 2012:315; Bultmann 1968:177; Buttrick 2000:108, 112-113; Crossan 1973:103; Deidun 1976:219, 222; Herzog 1994:135; Scott 1989:269). Finally, the addition of verse 35 also enables Matthew to turn the parable into a warning (Donahue 1988:74; Reid 2001:139, n. 22).

Matthew 18:34 was most probably also added by Matthew. As Perrin (1967:125) has indicated, Matthew 18:34 and 35 are required to convert the original challenge of the parable into a warning. The parable, he argues, without the Matthean redaction of Matthew 18:23 (see above), 'stand[s] pretty much as Jesus told it.' Oesterley (1936:99-100) also argues for Matthew 18:34 as a later addition, reflecting the apocalyptic interests of Matthew (see also Harnish 1995:259-262). Below it will be argued that the parable, when read through comparative social realia and through the lens of patronage

17.Jeremias (1972:210) has argued that ten thousand (as a number) and talent (as a currency unit) were the highest magnitudes in use in the whole of the Near East. Jesus inflated the figure in the parable to a magnitude of debt beyond conception to heighten the impression made on the audience by its contrast with the trifling deb of one hundred denarii of the second slave. Most scholars have followed Jeremias of one hundred denarii of the second slave. Most scholars have followed Jeremias in this interpretation (see Barclay 1970:87; Blomberg 2012:318; Boice 1983:183; Boucher 1981:117; Malina \& Rohrbaugh 2003:95). In Hertzog's (1994:135) view, of the parable as a type of political cartoon, and for Scott (1989:271) the figure of the parable as a type of political cartoon,
conjures up the high finance of the empire.

18.For a discussion of other suggestions, see Hultgren (2000:24, n. 10) and clientism, honour and shame, and reciprocity, form a unitary narrative when delimited to Matthew 18:23-33, excluding the Matthean additions to Matthew 18:23 (i.e. Si⿳亠

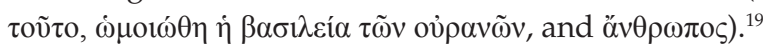

\section{Matthew 18:23-33: A realistic and social-scientific reading Realistic (and social-scientific) readings of the
parable}

Apart from the dominant allegorical-theological interpretations of the parable discussed in the history of the interpretation of the parable above, a few scholars have attempted a realistic reading of the parable against the backdrop of its social realia.

Herzog (1994:138-149), as first example, reads the parable against the backdrop of the extracting of tribute by rulers in agrarian (aristocratic) societies. The primary conflict in the parable is between a ruler and an important retainer at his court, and for the sake of contrast, between this highly placed retainer and other middle-level retainers. The king's initial decision to punish the servant, his subsequent decision to forgive the servant's debt, and his final withdrawal of mercy, expresses the ruler's absolute power and total command. The servant's failure to produce the expected tribute is part of the ongoing battle in bureaucracies to exert control; he has grown too confident in his power as retainer of the king. The king immediately recognises this, and asserts his control with his decision to punish the servant. When the servant reacts with desperation, as the king desired, the king reverses his previous decision. The servant again knows his proper place on the power scale, recognises the ultimate power of the king, and is therefore forgiven. As put by Herzog (1994):

He has been a good client and may be so again. Perhaps what is needed is an unexpected act of patronage generosity. ${ }^{20}$ So the king reverses himself, even forgiving the debt. (p. 142)

Because of what happened between the servant and the king, spread by gossip through the bureaucracy, the retainerservant now had to find ways to reassert his control. This he does by acting as a patron towards a middle-level bureaucrat, treating him as a client by demanding payment to show that he is as strong as ever. By this action the servant shames the king and violates his honour, making him look like a weak

19.Interpreters of the parable also suggest other possibilities in demarcating the parable used by Matthew. Weder (1984:211-218), for example, argues that the parable ends with Matthew 18:30 since the latter part of the parable relativises the focus on the mercy of God. Fuchs (1960:152:32-34) argues for the parable to end at Matthew 18:31, arguing that verses $32-35$ overstep the limits of the image of the king. Finally, some scholars argue for Matthew 18:23-35 as the parable used by Matthew. According to Snodgrass (2008:69), the parallel structure of the three acts in the parable demonstrates that Matthew 18:34 should be considered as part of the parable, while Matthew 18:35 is a typical Jewish nimshal and therefore should not be excluded. In the view of Boucher (1981:118) and Smith (1937:217, 219). Matthew 18:35 completes the intention of the parable, and therefore should be included. Hultgren (2000:35) makes a similar point: Matthew 18.35 is should be included. Hultgren (2000:35) makes a similar point. Matthew 18:35 is the application of the story, and makes the point of comparison in the parable as seen as ironic, indicating that within the story there is a sense of covenant; one's relationship with God is not a one-way affair.

20.See also Herzog (1994:146), where he describes the king's remission of the servant's debt as 'an extraordinary act, quite uncharacteristic of any agrarian ruler' 
fool. 'Backed into a corner, the king reverts with a vengeance to business as usual, delivering the courtier to the torturer' (Herzog 1994:147). What, according to Herzog, is the overarching message of the parable? The parable is about the fulfilment of sabbatical and messianic hopes. The act of the king to cancel the largest debt imaginable, Herzog argues, depicts a messianic moment; the messianic king has arrived and the messianic age has begun. What follows in the rest of the parable, however, shows the inadequacy of messianic hope and of kingship and the role of retainers (Herzog 1994:148). People will have to look elsewhere to reshape their world.

In a second realistic reading of the parable, Scott (1989:273278) sees in the parable a Gentile situation and tax farming. The parable itself is a tale that describes an accounting story in which a Gentile king will sit in judgement on those who must give account. An accounting story, Scott (1989:273) argues, invokes in a patron-client culture 'the hierarchical structure through which the patron sets things in order.' The enormous amount owed by the servant functions to distance the servant from the king. When the servant cannot pay up, the punishment dished out accentuates Gentile cruelty, an action forbidden by Jewish law. The master's decision to have pity on the servant, and his unexpected remission, calls Jewish superiority into question. The injustice of the first servant's action towards his fellow servant, however, reaffirms the stereotyped expectations of the Jewish hearers, confirming their stereotyped propaganda against Gentiles. When fellow servants of the king are outraged by the first servant's injustice, the hearer is drawn into the story, and identifies with the fellow servants. By doing this, they become like the Gentiles and forfeit their superiority. From this perspective, Scott (1989:278) argues, the parable is intended to reject Jewish notions of superiority, and indicates that the standards of this world are totally inadequate for the kingdom.

In a subsequent reading of the parable, Scott (1989:97-107) again emphasises the unexpected compassion of the secular ruler, and the relationship between the first and second slave is again described as a patron-client relationship between two unequals (Scott 1989:104). He also adds that what provoked the king were not economics or justice, but that the slave had violated the king's honour and shamed him by not following his example. Hence, the king had no other option than to protect his honour and thus wipe out the shame the slave brought upon him (Scott 1989:105). The king's initial forgiveness signalled the fulfilment of jubilee hopes, but the slave's lack of forgiveness brought this jubilee hope to an end, and the king's final action brought it crashing down. Therefore, the parable represents a fundamental challenge to popular notions of messianic kingship, and indicates that the system of patron-client distribution of power cannot distribute forgiveness or the blessing of jubilee (Scott 1989:105). Because of this, the parable implies that a wholly other system is needed, a system outside honour and shame, patron-client relation and royal power. As such, the parable points to the corruption and irredeemable character of a world organised by imperial rule (Scott 1989:107).
A third realistic reading of the parable is that of Derrett (1970:32-47). Like Scott, Derrett sees the backdrop of the parable as tax farming, with the servant failing to honour his contract with the king. The king's release of the servant's debt is based on two reasons: Firstly, he needed the servant's specialised skill and his vast network of clients to extract tribute from the provinces. Secondly, the king, on a point of honour, saw his release of the servant's debt as the first in a series of actions to lighten the burdens of his provinces, breaking the cycle of ruthless exploitation and extraction (Derrett 1970:41). The servant's release of debt thus was provisional; he now had to follow the example set by the king (Derrett 1970:42). When the servant does not release the debt of a fellow servant he does not act on the king's example, and continues the cycle of extraction and exploitation. Thus, what was meant to initiate acts of debt remission has come to a halt with the servant's action. This left the king with no other option but to defend his honour and release the first servant from his position (Derrett 1970:43). ${ }^{21}$

Below it will be indicated that Scott and Herzog's interpretation of the parable through the lens of patronage and clientism are most probably correct and helpful in reading the parable in terms of its social realia. It will, however, be indicated that both these scholars do not apply the salient features of patronage and clientism in a consistent manner. Also, they do not take comparative social realia into consideration when interpreting the parable. As a result, both misinterpret the motive of the patron's release of the debt of the first servant (excluding Scott's second reading on this point), as well as the second scene of the parable (the interaction between the first and second servant). Moreover, their understanding of the release of the first servant's debt as an unexpected act of patronage generosity is incorrect, as evidenced by documented papyri. It will also be indicated that all three scholars' inclusion of Matthew 18:34 as part of the parable seriously flaw their interpretations. The parable is not about the exertion of control by patrons or retainers challenging the power of patrons (Herzog), the inadequacy of messianic hope and kingship (Herzog and Scott), Jewish superiority (Scott), or the ending of the cycle of ruthless exploitation and extraction by the elite (Derrett) - which, by the way, is unthinkable in any agrarian society. Above all, contra Herzog and Scott, the parable does not suggest that the hearers of the parable should look elsewhere, outside honour and shame, patronclient relation, royal power and empire to reshape their world. On the contrary, the kingdom is to be found in the parable especially where debt release is driven by ascribed honour.

\section{Patronage, debt release and honour as backdrop of the parable}

Bazzana (2011:511-525), in a recent study on the forgiveness of debts in the Lord's Prayer (Q 11:2b-4), again has indicated the important contribution documentary papyri can make to

21.Another realistic interpretation of the parable is that of Beutner $(2007.35-37)$ that is only mentioned here in brief. According to Beutner, the parable is about the adversarial, crooked, alien and dangerous world of the 1st-century patronage system under which the peasants lived. When Jesus tells a parable about a system under which the peasants lived. When Jesus tells a parable about a
despised elite king who uses his authority to release debt, Jesus is indicating in despised elite king who uses his authority to release debt, Jesus
which way authority should be exercised in the kingdom of God. 
the historical and exegetical study of ancient Christian texts

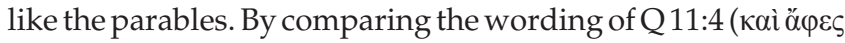

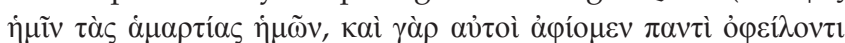

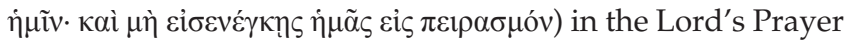
with documented Ptolemaic amnesty decrees, he shows that key ideas in the prayer (the cancellation of debts and the euergetic characterisation of God's kingdom) 'may have reminded readers and hearers of Hellenistic royal ideology' (Bazzana 2011:511). In reading the prayer, Bazzana suggests, the readers 'imagined the awaited divine sovereignty by reversing and reinscribing certain cultural symbols spread in the eastern regions of the Mediterranean by Hellenistic royal propaganda' (Bazzana 2011:511).

In the Lord's Prayer the request for release of personal debts and the debt of others are described as ' $\alpha$ $\varphi \varepsilon \varsigma . . . ~ o ́ \varphi \varepsilon \imath \lambda \eta$ $\mu \alpha \tau \alpha^{\prime}$

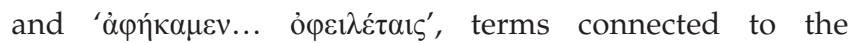

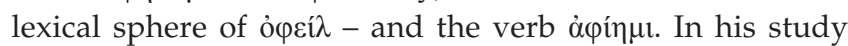
of available documented papyri, Bazzana identifies five documents (P. Hib. 1.41; P. Köln 7.313; SB 20.14106; P. Oxy. 2.237 8.7-1; Chr. Wilck. 29) 22 in which this word pair occurs, showing a significant connection. In P. Hib. 1.41 (Hibeh, 261 BCE), the phrase 'allow him to collect the arrears', is

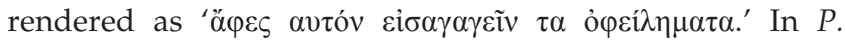
Köln 7.313 (Oxyrhynchus 2nd century BCE; a royal decree promulgated in $186 \mathrm{BCE}$ to celebrate, with an amnesty for crimes and debts, King Ptolemy V's victory over a rebellion in southern Egypt), the release of debt on leases and dikes

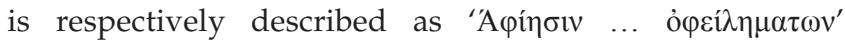
and 'A from proprietors on vineyards and orchards and baths as 'A unknown $18 \mathrm{BCE}$ ), the release of debts is described with

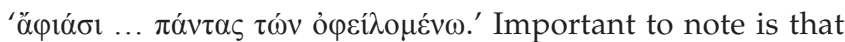
this document, as in the case of $P$. Köln 7.313, is a decree wherein Ptolemy and Cleopatra proclaim inter alia a release of debt in respect to the farming of the grain tax and the money taxes in the 50th year of reign of the king Ptolemy. In P. Oxy. 2.237 8.7-13 (Oxyrhynchus 186 CE) debtors and

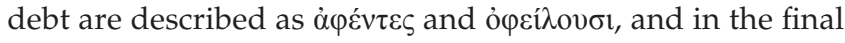

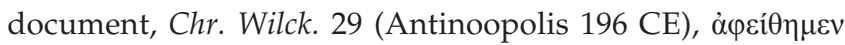
is used for the exemption from any kind of liturgies, and

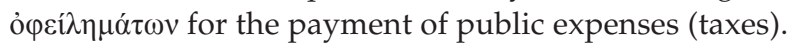

In his analysis of the above papyri, Bazzana makes three important observations: Firstly, the enforcement of these Ptolemaic ordinances was usually not restricted only to debt due to the royal treasury; the cancellation of debt was extended to what each subject in the kingdom owed one another (see P. Köln 7.313, 24-25; P. Tebt 1.5.221-47; Bazzana 2011:517). ${ }^{23}$ As indicated by Bazzana:

$[I] \mathrm{n}$ royal decrees ... the remittance granted by the sovereign was extended to the private sphere of economic relationships. Hence,

22. For a detailed description of the background, context and content of these papyri, see Bazzana (2011:514-517).

23.See also similar provisions in BGU 4.1156.24 (Alexandria $15 \mathrm{BCE}$ ) and BGU 1053.2, 7 (Alexandria 13 BCE). As Bazzana (2011:517) explains: 'In both of these deeds of loan it is stated that the debtor will have to repay the money, even though the

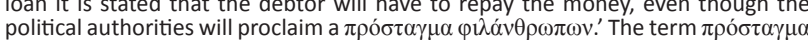

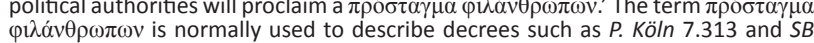
$\varphi 1 \lambda \alpha \dot{\alpha} \theta \rho \omega \pi \omega v$ is normally used
20.14106 described above. the subjects were forced to assimilate their own behavior to the king's and, through this act of obedience, to reinscribe the image of the king as the ideal broker of divine providence to the world. (pp. 523-524)

Secondly, the royal habit of conceding debt remittances was not a practice restricted only to the Ptolemaic kingdom in Egypt. Available evidence indicates that the forgiveness of debts was also part of an ideology present in other areas of the eastern Mediterranean and in the land of Israel (Bazzana 2011:517). Herodotus (Hist 6.59), for example, refers to the tradition of Spartan and Persian kings, when taking office, to release all their subjects from debt, and both Arrian (Anab. 7.5) and Diodorus Siculus (Bibl. hist. 17.109.12) mention Alexander's liquidation of all his soldiers' debts after his return to Babylon from India. According to Bazzana (2011:518), this precedential act by Alexander became a standard feature of Hellenistic royalty. Finally, 1 Maccabees 13:36-39, cites an official letter of Demetrius II (the new Seleucid king) addressed to Simon the high priest, the elders and the Jewish people, which shows that the habit of releasing debt at the inception of a new reign was also practiced in the land of Israel. In this apocryphal text, Demetrius undertakes to remit ( $\dot{\alpha} \varphi \dot{\varepsilon} \mu \varepsilon v)$ inter alia the crown tax that is owed ( $\omega \varphi \varepsilon i \hat{\lambda} \varepsilon \tau \varepsilon)$ by the temple, as well as any other tax that may have been collected in Jerusalem (1 Macc 13:39).

Thirdly, a few documentary papyri (see P. Münch 3/1.45.2; UPZ 1.113.6; P. Tor. Choach. 12.7.14 and BGU 8.1764.1, 5, in Bazzana 2011:520-521) connect the royal decrees on remittance of debts to the concept of basileia, indicating that it was of paramount importance for Hellenistic sovereigns to care for the welfare and prosperity of their subjects (Bazzana 2011:521).

Bazzana's conclusion of his analysis of the above-mentioned texts is that these texts 'make it easy to see how the first hearers and readers of the Lord's Prayer may have connected the Christian text with their everyday experience' (Bazzana 2011:517).

Taking Bazzana's analysis of these texts into consideration, the same case can be made with regards to the Unmerciful Servant because of the obvious correspondences between these papyri and the parable. Firstly, in the parable the terms used for debt and debtor ${ }^{24}$ and the release of the debt ${ }^{25}$ of the first servant show close similarities with the lexical sphere

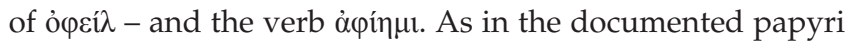
discussed by Bazzana, the word pair ỏpeí - and the verb

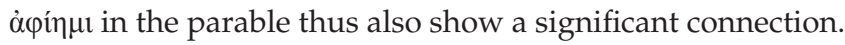
Secondly, the king's release of the debt of the first servant in the parable is reminiscent of the release of debt in especially P. Köln 7.313, SB 20.14106 and 1 Maccabees 13:39. Based on these three correspondences, and the fact that the royal habit of releasing debt was also part of an ideology present in the

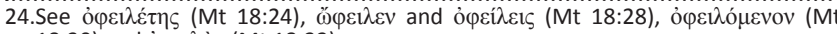

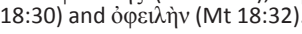

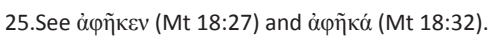


land of Israel (1 Macc 13:39), ${ }^{26}$ it is not difficult to see that the first hearers of the Unmerciful Servant may have connected the social realia in the parable with their everyday experience.

Below it will be indicated that, when the Unmerciful Servant is read against the background of attested royal ideology on debt release in especially P. Köln 7.313, SB 20.14106 and 1 Maccabees 13:39, the parable suggests that in the basileia of God, debt should be released in terms of general reciprocity, emulating the way in which patrons release debt for the sake of honour.

\section{Reading the parable}

Matthew 18:23-25 sets the scene of the parable. A king wishes to settle his accounts, a servant who cannot pay is brought before him and the king orders the servant to be sold with his family and his belongings to cover the outstanding debt. This introductory scene evokes two sets of political and social realia. Firstly, the decision of the king to sell the servant indicates that the king is non-Jewish since the sale of a wife was absolutely forbidden under Jewish law (Jeremias 1972:211). The parable thus depicts a non-Jewish (Gentile) situation. ${ }^{27}$

The second set of social realia implied by the introductory scene is that of patronage and clientism. Patronage and clientism was part and parcel of aristocratic (advanced agrarian) societies like the 1st-century Mediterranean world. ${ }^{28}$ In aristocratic societies political power was obtained and exercised inter alia through patronage (see Saller 1982:41-78, 119-143). Those in the upper echelons of political power, like kings (rulers), could not rule without developing patron-client relationships. These patron-client relationships were socially fixed, based on a strong element of inequality (already implicit in the term cliens) and difference in power, were voluntary and reciprocal, focused on honour and respect, and were held together by loyalty (a strong binding long-range, social-interpersonal obligation). The basic structure of these relationships, finally, was an exchange of different and very unequal resources. A patron had social, economic and political resources that were needed by a client. By being granted a favour, the client implicitly promised to pay back the patron whenever and however the patron determined..$^{29}$

26.See also Midr. Tanhumah Emor 8.30 (on Lv 23:39-40), that has a parable in which a king forgives the taxes owed by one of his provinces. Although this text is part of the later Jewish writings, and employs the parable as an example of how God forgives, the text gives evidence of knowledge of the royal ideology how God forgives,
of releasing debt.

27. Under Roman law this was normal practice (see e.g. Diogenes Laertius, Bion $4.46-47)$. For the prohibition in Jewish law to sell a debtor's wife, see $m$. Soto 3.8, m. Gittten 4.9, t. Soța 2.9 and Sifre Deut. 26. Snodgrass (2008:69), on the basis that Sifre Deut. 26 does not explicitly mention a Gentile king, argues that the parable 'do not necessarily indicate a Gentile context.' This is an argumentum ex silentio that can simply be reversed, since the text neither explicitly mentions a Jewish king.

28.Seneca (Benefits 1.2.1) goes so far as to call it 'a practice that constitutes the chief bond of human society.'

29.For the salient features of patronage and clientism, see Eisenstadt and Roniger (1980:42-77, 1984:48-49); Saller (1982); Moxnes (1991:241-268); Wallace-Hadril (1989:63-87); Malina (1996:143-147); Malina and Rohrbaugh (2003:388) and Neyrey (2005:465-492)
When looking through this lens at the relationship between the king and the servant in the parable, it is clear that the parable has all the markings of a patron-client relationship. Firstly, the relationship is based on a strong element of inequality and difference in power. The servant most probably is an official serving the king, ${ }^{30}$ indicating the unequal status between the king and the servant; an inequality confirmed in the parable

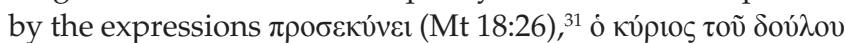

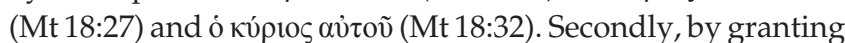
the servant a loan ( the servant by giving him access to economic and political resources otherwise not available. Finally, by accepting the loan, the servant promised to pay back the loan as and when determined by the king. In the parable, this moment had now arrived. The client (servant) now has the opportunity to show his loyalty towards his patron.

When the servant cannot pay his debt, the king's first decision is to sell the servant to make up for his loss (Mt 18:25). The servant, however, desperately begs ( $\pi \rho \circ \sigma \varepsilon \kappa v ́ v \varepsilon 1)$ the king to have patience until he is able to pay his debt (Mt 18:26). The king then, because of this request and out of compassion ( $\sigma \pi \lambda \alpha \gamma \chi \nu 1 \sigma \theta \varepsilon i \varsigma)$, decides to overturn his initial decision and releases the debt of the servant. To avoid an anachronistic reading of the parable, the importance of interpreting this decision of the king against the background of the social realia of the parable cannot be stressed enough.

In patron-client relationships it was not only expected of the client to behave in specific ways. Because patronclient relationships involved a strong element of personal obligation, it was expected of patrons to show generosity (Moxnes 1991:249; Neyrey 1991:370). As put by Malina and Rohrbaugh (2003):

[T] he king decides to act in terms of 'mercy', that is, an appeal to his royal honor to pay his debts of interpersonal obligation to a 'household member'. On the basis of such 'mercy' the king forgives the debt. (pp. 95-96) (33 $^{33}$

That the king's mercy is indeed part of his motivation to release the debt of the slave is attested in Matthew 18:33, when the

30.According to Jeremias (1972:210), in the East the term 'servants of the king' was normally used for higher officials. The possibility that the servant was a provincia governor (Boucher 1981:117; Linnemann 1980:108; Wenham 1989:152), a tax farmer (Hultgren 2000:24; Scott 1989:270; Snodgrass 2008:68), a retainer (Herzo 1994:137), or even a slave (see Beavis 1992:37-54; Glancy 2000:67-90) makes no difference in the interpretation of the parable. What matters, and this is makes no the parable, is that the king (patron) and the servant (client) are of unequal status.

31.The word $\pi \rho 0 \sigma \varepsilon \kappa v ́ v \varepsilon 1$ is 'often used of obeisance by an inferior to a superior' (Snodgrass 2008:69).

32.Again, it does not matter for the interpretation of the parable whether the debt of the servant was incurred as a result of the under-collecting of taxes from his province (Boucher 1981:117; Herzog 1994:140; Jeremias 1972:210; Linnemann 1980:108; Malina \& Rohrbaugh 2003:95; Reid 2001:135; Schippers 1962:136; Via 1967:138); that the servant did not honour his contract with the king as a tax farmer (Hultgren 2000:24; Schottroff 2006:197; Scott 1989:270; Snodgrass 2008:68); that the servant was in arrears paying back a loan (De Boer 1988:47; Lambrecht 1992:157; Manson 1949:213; Morgan 1953:92); or that the debt of a tax farmer was turned into a loan (Derrett 1970:36-37). Important for the of a tax farmer was turned into a loan (Derrett 1970:36-37). Important for the favour (debt) in. Also see Jon ó́vciov in reference to debt incurred.

33.See also Malina (1993:86): 'Those toward whom one has such a debt are equally obliged to maintain the relationship by further favors ... the mercy involved is not simply feelings of compassion for one who suffers unjustly, but paying one's debt of interpersonal obligation by forgiving ... debt.' 
king affirms that he forgave the servant out of mercy (кỏyஸे

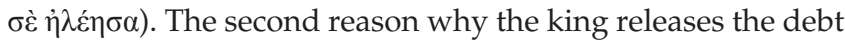
of the servant, linked to the element of personal obligation, seems to be his desire for repute and honour. Patron-client relationships contained a strong element of solidarity that was sealed by exchange, often couched in terms of interpersonal loyalty and attachment between patrons and clients (Sahlins 1972:220; Wallace-Hadrill 1989:72). This solidarity, as indicated by Eisenstadt and Roniger (1980:50), was 'often closely related to conceptions of personal identity, especially of personal honor.' Thus, what the patron loses in material wealth would be more than compensated for in honourable reputation. The motive force behind the seeking of public honour was philotīmia [love of honour], and, as versed by Dover (1974:230), 'the advantage sought by philotimiā was inter alia the reputation which was brought about by the discharge of financial obligations.' Thus, because the king expected that the servant would enhance his reputation after the release of his debt on an ongoing basis by repeated public praise of his 'merciful' patron, ${ }^{34}$ the king released his debt (Hobbs 1997:502-503; Pilch 1999:62; see also Malina 1993:87; Moxnes 1991:250).

For the modern interpreter of the parable, the release of the debt by the patron-king because of personal obligation and the search for public honour seems incredible. The reason for this is that we as moderns read into the text our own political and social context of a Western style democracy with a central government and bureaucracy wherein everybody expects to have equal access to goods and services provided by the state (see Moxnes 1991:243). To understand the social realia in ancient texts, cultural awareness of the 'other' and cultural self-awareness are needed. Added to this, as Kloppenborg (2014b:2) has insisted, we need to assemble solid ancient comparanda on the practices and social realities which the sayings of Jesus and the parables presuppose.' In the case of the Unmerciful Servant, this comparanda is provided by the practice of patronage (as described above), and the social realities depicted in P. Köln 7.313, SB 20.14106 and 1 Maccabees 13:39. In these documented papyri there is not only a similarity with regards to the lexical sphere of ópri $\lambda$ - and the verb $\alpha \varphi i ́ \mu 1$, but also the social reality depicted in the Unmerciful Servant is mirrored. In these three documents kings (Ptolemy V, Ptolemy and Demetrius II) release the debts of their subjects. This was political power at play between rulers (patrons) and subjects (clients); relationships based on a strong element of inequality and difference in power. And since political power in these aristocratic societies was exercised by developing patron-client relationships, it is not difficult to see that the first hearers of the Unmerciful Servant connected the social realia in the parable with these releases of debt. Also, the hearers of the parable would have taken it for granted that these releases of debt as acts of royal care for subjects were aimed at acquiring honour.

34.That this was expected from the client (unequal) in patron-client relationships is for example clear from P. Mert 1.12.6-9 (dated 26 April 58). In this personal letter, most probar a addressee (Dionysius) are friends (equals), he "may dispense with writing to you with a great show of thanks; for it is for those who are not friends that we must give

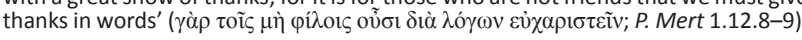

Based on the correspondences between these texts and the parable, the release of the debt of the servant by the king in the parable was not interpreted by its hearers as unexpected compassion (Scott 1989:104), an 'unexpected act of patronage generosity' (Herzog 1994:142) or an act 'quite uncharacteristic of any agrarian ruler' (Herzog 1994:146). For the hearers of the parable the release of the debt of the servant was quite ordinary. For them this was no surprise. This is how rulers act; in their constant quest for honour (philotimiāa) they turn their subjects with acts of 'mercy' into clients who then had to reciprocate with word of mouth in public as recognition of received generosity.

The scene between the two servants (Mt 18:28-30), and the decision of the first servant not to release a much smaller debt (Mt 18:31), can also be understood against the social realia evoked by the documented papyri discussed by Bazzana. As Bazzana has indicated, the enforcement of the Ptolemaic ordinances was usually not restricted only to debt due to the royal treasury, but extended to what each subject in the kingdom owed one another (see again P. Köln 7.313, 24-25; P. Tebt 1.5.221-47). Thus, when the second servant asked the servant whose debt had been released also to have patience until he could pay his debt, the expectation of the other servants looking on would have been twofold: Firstly, the servant will honour the king by proclaiming his release of debt openly, and secondly, as act of obedience and personal obligation as client of the king, assimilate his behaviour to that of the king by also releasing the debt of his fellow servant, most probably someone of equal status

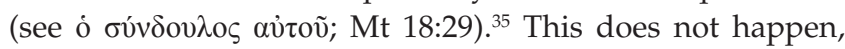
and by his decision the servant instead shames the king. The other servants, most probably also clients of the king acting inter alia as his informers (see Herzog 1994:142), report what happened to the king, where after the first servant is summoned.

Then comes the surprise in the parable. Thus far the story in the parable developed as expected in terms of its known social realia and the everyday experiences of its hearers. Kings forgive debt in search of honour, and clients reciprocate accordingly. Patron-client relationships between unequal persons entailed balanced reciprocity (the serving of mutual interests; Malina 1986:98-106; Neyrey 2004:253; 2005:469470). These relationships were based on personal obligation, solidarity and loyalty, not on altruistic motives in the sense of extreme solidarity (generalised reciprocity). Thus, although it had a kinship glaze over it (see Dionysius of Halicarnassus, Ant. rom.2.9), it was 'a system dominated by the elite (patrons) and their values; a system that was set up in order to ensure the preservation of their privileged positions and power' (Van Eck 2011:10; see also Moxnes 1991:244). As such, the purpose of patron-client relationships - while masking 'the

35.Several scholars have argued that the second servant should be positioned at a lower end of the social hierarchy, and thus of unequal status to that of the first servant. Jeremias (1972.212), for example, identifies the second servant as a minor (1) middle-class bureaucrat. That the two servants are of equal status is clear from the

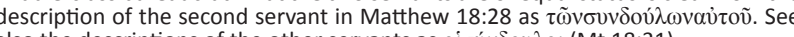
also the descriptions of the other servants as oívívoovior (Mt 18:31). 
fundamentally unbalanced and exploitative nature of the exchange' (Kloppenborg 2014b:492) - was to exercise power over others, a core value of advanced agrarian societies (see Hanson \& Oakman 1998:72; Herzog 2005:55; Oakman 2008:138-142). ${ }^{36}$

Therefore, when the first servant did not reciprocate as was expected, the king had to defend his honour, power and privilege. In a world where honour and power were core values, it was considered as shameful not to defend one's honour and power. But this is exactly what the king does. Totally unexpected, he does not react with a defence of honour, or in the first servant's typical and socially accepted ruthless way. This is clear from his words in Matthew 18:33: When someone asks for the release of his debt, you show mercy without expecting a socially prescribed response. Honour does not lie in the eye of the beholder, but in the act itself. The release of debt should be given altruistically, that is, not in terms of balanced reciprocity, but in terms of general reciprocity. Where this happens, the basileia of

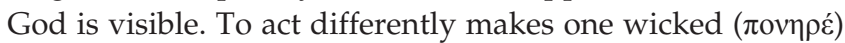
(Mt 18:33).

Read from this perspective, Jesus uses the parable to question 1st-century Mediterranean social relations based on balanced reciprocity and on the pivotal value of honour. A world based on the value of honour is dominated by the powerful and ensures the preservation of privileged positions and power, and, because it is fundamentally unbalanced, leads to exploitation and debt. This world is not the basileia. On the contrary, the basileia of God is present where debt release, in the act itself, is the honourable thing to do. At the end of the parable, this option is left in the midst of the hearers of the parable implied by the rhetorical question in Matthew 18:33.

\section{A parable of Jesus?}

Most scholars see the Unmerciful Servant as going back to an earlier parable of Jesus (see e.g. Crossan 1973:103; Davies \& Allison 1997:794; Funk et al. 1993:218; Jeremias 1972:212; Hultgren 2000:29; Linnemann 1980:106). The above interpretation concurs with this point of view. The parable has all the hallmarks of a Jesus parable, typically cutting against the grain of several practices and values dominating his social world. The king's stance on honour, for example, is paralleled in Thomas 65 where the owner refrains from violence and does not try to defend his honour and status (see Van Eck 2007:909-936). This is also the case in the parable of the Feast (Lk 14:16b-23) were the host, after being shunned by his elite invitees, fills up his table with those without any honour (see Van Eck 2013:1-14). This stance of Jesus on general reciprocity in the parable also parallels his sayings in Q 6:27-28, 29, 30, 33, Q 11:33 (see Howes 2013:311-315) and Q 12:42-46 (see Howes 2014:6).

36.See also Elliott (2008:29): "The codes of patronage effectively masked the deeply exploitative nature of the tribute- and slave-based economy by simultaneously
concealing the rapacity of the ruling class and naturalizing fundamentally unequal concealing the rapacity of the ruling class and naturalizing
relationships through routines of theatrical reciprocity.'

\section{Acknowledgements Competing interests}

The author declares that he has no financial or personal relationships which may have inappropriately influenced him in writing this article.

\section{References}

Barclay, W., 1970, The parables of Jesus, Westminster John Knox Press, Louisville, KY.

Bazzana, G.V., 2011, 'Basileia and debt relief: The forgiveness of debts in the Lord's Prayer in the light of documentary papyri', The Catholic Biblical Quarterly 73, 511-525.

Beavis, M.A., 1992, 'Ancient slavery as an interpretive context for the New Testament servant parables with special reference to the Unjust Steward (Luke 16:1-8)', Journal of Biblical Literature 111(1), 37-54. http://dx.doi.org/10.2307/3267508

Beutner, E.F., 2007, 'A mercy unextended: Matthew 18:23-43', in E.F. Beutner (ed.), Listening to the parables of Jesus, pp. 33-39, Polebridge Press, Santa Rosa, CA (Jesus Seminar Guides, 2).

Blomberg, C.L., 2004, Preaching the parables: From responsible interpretation to powerful proclamation, Baker Academic, Grand Rapids, MI.

Blomberg, C.L., 2012, Interpreting the parables, 2nd edn., InterVarsity Press, Downers Grove, IL.

Boice, J.M., 1983, The parables of Jesus, Moody Press, Chicago, IL.

Borg, M.J., 2006, Jesus: Uncovering the life, teachings, and relevance of a religious revolutionary, HarperCollins, New York, NY.

Boucher, M.I., 1981, The parables, Michael Glazier Inc., Wilmington, DE. (New Testament Message, 7.)

Brouwer, A.M., 1946, De gelijkenissen, A.W. Sijthoff's Uitgeversmaatschappijy N.V. Leiden.

Bultmann, R., 1968, History of the synoptic tradition, transl. J. Marsh, Blackwell, Oxford.

Buttrick, D., 2000, Speaking in parables: A homiletical guide, Westminster John Knox Press, Louisville, KY.

Capon, R.F., 1988, The parables of grace, Wm. B. Eerdmans Publishing Co., Grand Rapids, MI.

Crossan, J.D., 1973, In parables: The challenge of the historical Jesus, Harper \& Row, New York, NY.

Davie, G.J. (ed.), [1888] 2007, John Maldonatus - a commentary on the holy gospels: S. Matthew's gospel, transl. G.J. Davie, John Hodges, London.

Davies, W.D. \& Allison, D.C., 1997, A critical and exegetical commentary on the gospel according to Saint Matthew, vol. 2, T\&T Clark, Edinburgh. (ICC.)

De Boer, M.C., 1988, 'Ten thousand talents? Matthew's interpretation and redaction of the parable of the unforgiving servant (Matt. 18:23-35)', Catholic Biblical Quarterly 50(2), 214-232.

Deidun, T., 1976, 'The parable of the unmerciful servant' (Mt. 18:23-35)', Biblical Theological Bulletin 6, 203-224.

Derrett, J.D.M., 1970, Law in the New Testament, Darton, Longman, \& Todd, London.

Dietzfelbinger, C., 1972, 'Das Gleichnis von der erlassenen Schuld: Eine theologische Untersuchung von Matthäus 18, 23-35', Evangelische Theologie 32, 437-451. http://dx.doi.org/10.14315/evth-1972-jg32

Dodd, C.H., 1961, The parables of the kingdom, Charles Scribner's Sons, New York, NY.

Donahue, J.R., 1988, The gospel in parable: Metaphor, narrative and theology in the Synoptic gospels, Fortress Press, Philadelphia, PA.

Dover, K.J., 1974, Greek popular morality: In the time of Plato and Aristotle, Basil Blackwell, Oxford.

Drury, J., 1985, The parables in the gospels: History and allegory, Crossroad, New York,

Dwight, J., 1982, The parables of Jesus: Lessons in life from the master teacher, Kregel Publications, Grand Rapids, MI.

Eisenstadt, S.N. \& Roniger, L., 1980, 'Patron-client relations as a model of structuring social exchange', Comparative Studies in Society and History 22, 42-77. http:// dx.doi.org/10.1017/S0010417500009154

Eisenstadt, S.N. \& Roniger, L., 1984, Patrons, clients and friends: Interpersonal relations and the structure of trust in society, Cambridge University Press, Cambridge.

Elliott, J.H., 1993, What is social-scientific criticism? Fortress Press, Minneapolis, MN. (Guides to Biblical Scholarship) http://dx.doi.org/10.1017/CBO9780511557743

Elliott, N., 2008, The arrogance of nations: Reading Romans in the shadow of empire (Paul in critical contexts), Fortress Press, Minneapolis, MN

Ford, R.Q., 1997, The parables of Jesus: Recovering the art of listening, Fortress Press, Minneapolis, MN.

Fuchs, E., 1960, Zur Frage nach dem historischen Jesus, JCB Mohr, Tübingen.

Funk, R.W., 2007, 'Jesus of Nazareth: A glimpse', in E.F. Beutner (ed.), Listening to the parables of Jesus, pp. 89-93, Polebridge Press, Santa Rosa, CA. 
Funk, R.W., Hoover, R.W. \& The Jesus Seminar, 1993, The five gospels: The search for the authentic words of Jesus, Macmillan, New York, NY.

Glancy, J.A., 2000, 'Slaves and slavery in the Matthean parables', Journal of Biblical Literature 119(1), 67-90. http://dx.doi.org/10.2307/3267969

Groenewald, E.P., 1973, In gelykenisse het Hy geleer, N.G. Kerk-Uitgewers, Kaapstad.

Hanson, K.C. \& Oakman, E., 1998, Palestine in the time of Jesus: Social structures and social conflicts, Fortress Press, Minneapolis, MN.

Harnish, W., 1995, Die Gleichniserzälungen Jesu: Eine hermeneutische Einführung, Vandenhoeck \& Ruprecht, Göttingen.

Herzog, W.R., 1994, Parables as subversive speech: Jesus as pedagogue of the oppressed, Westminster, Louisville, KY.

Herzog, W.R., 2005, Prophet and teacher: An introduction to the historical Jesus, Westminster John Knox Press, Louisville, KY.

Hobbs, T.R., 1997, 'Reflections on honor, shame, and covenant relations', Journal of Biblical Literature 116(3), 501-503. http://dx.doi.org/10.2307/3266671

Howes, L., 2013, 'Placed in a hidden place: Illuminating the displacement of Q 11:33, 34-35', Neotestamentica 47(2), 303-332.

Howes, L., 2014, 'Food for thought: Interpreting the parable of the loyal and wise slave in Q 12:42-46', paper presented at the Perspectives on the socially disadvantaged in early Christianity conference, University of the Free State, Bloemfontein, 23 October.

Hultgren, A.J., 2000, The parables of Jesus: A commentary, William B. Eerdmans Publishing Company, Grand Rapids, MI.

Hunter, A.M., 1960, Interpreting the parables, Westminster Press, Philadelphia, PA.

Hunter, A.M., 1971, The parables: Then and now, Westminster Press, Philadelphia, PA.

Inrig, G., 1991, The parables: Understanding what Jesus meant, Discovery House Publishers, Grand Rapids, MI.

Jeremias, J., 1972, The parables of Jesus, SCM Press Ltd, London.

Keach, B., 1978, Exposition of the parables in the Bible, Kregel Publications, Grand Rapids, MI.

Kendall, R.T., 2006, The parables of Jesus: A guide to understanding and applying the stories Jesus told, Chosen Books, Grand Rapids, MI.

Kissinger, W.S., 1979, The parables of Jesus: A history of interpretation and bibliography, The Scarecrow Press, Metuchen, NJ.

Kistemaker, S.J., 1980, The parables: Understanding the stories Jesus told, Baker Books, Grand Rapids, MI.

Kloppenborg, J.S., 2006, The tenants in the vineyard: Ideology, economics, and agrarian conflict in Jewish Palestine, Mohr Siebeck, Tübingen (Wissenschaftliche Untersuchungen zum Neuen Testament, 195).

Kloppenborg, J.S., 2011, 'The representation of violence in Synoptic parables', in E-M. Becker \& A. Runesson (eds.), Mark and Matthew I. Comparative readings: Understanding the earliest gospels in their first-century settings, pp. 323-351, Mohr Siebeck, Tübingen.

Kloppenborg, J.S., 2014a, 'The parable of the burglar in Q: Insights from papyrology', in D.T. Roth, R. Zimmermann \& M. Labahn (eds.), Metaphor, narrative, and parables in Q, pp. 287-306, Mohr Siebeck, Tübingen.

Kloppenborg, J.S., 2014b, Synoptic problems: Collected essays, Mohr Siebeck, Tübingen. (Wissenschaftliche Untersuchungen zum Neuen Testament, 329).

Lambrecht, J., 1992, Out of the treasure: The parables in the gospel of Matthew Peeters Press, Louvain. (Louvain Theological \& Pastoral Monographs, 10).

Linnemann, E., 1966, Jesus of the parables: Introduction and exposition, 3rd edn., transl. J. Sturdy, Harper \& Row, New York, NY.

Linnemann, E., 1980, Parables of Jesus: Introduction and exposition, 5th edn., transl. J. Sturdy, SPCK, London.

Lockyer, H., 1963, All the parables of the Bible, Zondervan, Grand Rapids, MI.

Luz, U., 2012, Das Evangelium nach Matthäus, vol. 3, Mt 18-25, 2. Aufl., Benziger Verlag, Zurich. (Evangelisch-katholischer Kommentar zum Neuen Testament, $1 / 3)$.

Malina, B.J., 1986, Christian origins and cultural anthropology: Practical models for biblical interpretation, John Knox Press, Atlanta, GA.

Malina, B.J., 1993, 's.v. Hospitality', in B.J. Malina \& J.J. Pilch (eds.), Biblical social values and their meaning: A handbook, Hendrickson Publishers, Peabody, MD, pp. 86-87.

Malina, B.J., 1996, The social world of Jesus and the gospels, Routledge, London.

Malina, B.J. \& Rohrbaugh, R.L., 2003, Social science commentary on the Synoptic gospels, 2nd edn., Fortress Press, Minneapolis, MN.

Manson, T.W., 1949, The sayings of Jesus, SCM Press, London.

Morgan, G.C., 1953, The parables and metaphors of our Lord, Marshall, Morgan \& Scott, Ltd., London.
Moxnes, H., 1991, 'Patron-client relations and the new community in Luke-Acts', in J.H. Neyrey (ed.), The social world of Luke-Acts: Models for interpretation, pp. 241-268, Hendrickson, Peabody, MD.

Neyrey, J.H., 1991, 'Ceremonies in Luke-Acts', in J.H. Neyrey (ed.), The socia world of Luke-Acts: Models for interpretation, pp. 361-387, Hendrickson, Peabody, MD.

Neyrey, J.H., 2004, Render to God: New Testament understandings of the divine, Fortress Press, Minneapolis, MN

Neyrey, J.H., 2005, 'God, benefactor and patron: The major cultural model for interpreting the deity in Greco-Roman antiquity', Journal for the Study of the New Testament 27(4), 465-492. http://dx.doi.org/10.1177/0142064X05055749

Oakman, D.E., 2008, Jesus and the peasants, Cascade Books, Eugene, OR. (Matrix: The Bible in Mediterranean context, 4).

Oesterley, W.O.E., 1936, The gospel parables in the light of their Jewish background, SPCK, London.

Origen, Commentary on Matthew XIV, 13, viewed 15 September 2014, from http:// www.newadvent.org/fathers/101614.htm

Perkins, P., 1981, Hearing the parables of Jesus, Paulist Press, New York, NY.

Perrin, N., 1967, Rediscovering the teaching of Jesus, Harper \& Row, New York, NY.

Pilch, J.J., 1999, The cultural dictionary of the Bible, The Liturgical Press, Minneapolis, $\mathrm{MN}$

Robinson, J.M, Hoffmann, P. \& Kloppenborg, J.S. (eds.), 2000, The critical edition of Q: Synopsis including the gospels of Matthew and Luke, Mark and Thoma with English, German, and French translations of $Q$ and Thomas, Fortress Press, Minneapolis, MN. (Hermeneia - A critical and historical commentary on the Bible, Supplements).

Rohrbaugh, R.L., 2006, 'Hermeneutics as cross-cultural encounter: Obstacles to understanding', HTS Teologiese Studies/Theological Studies 62(2), 559-576. http://dx.doi.org/10.4102/hts.v62i2.365

Reid, B.E., 2001, Parables for preachers: The gospel of Matthew, The Liturgical Press, Collegeville, PA.

Sahlins, M., 1972, Stone age economics, Aldine Publishing Company, New York, NY.

Saller, R.P., 1982, Personal patronage under the early empire, Cambridge University Press, Cambridge. http://dx.doi.org/10.1017/CBO9780511583612

Schippers, R., 1962, Gelijkenissen van Jezus, J. H. Kok N.V, Kampen.

Schottroff, L., 2006, The parables of Jesus, transl. L.M. Maloney, Fortress Press, Minneapolis, MN.

Scott, B.B., 1989, Hear then the parable: A commentary on the parables of Jesus, Fortress Press, Minneapolis, MN.

Smith, B.T.D., 1937, The parables of the synoptic Gospels: A critical study, Cambridge University Press, Cambridge.

Snodgrass, K.R., 2008, Stories with intent: A comprehensive guide to the parables of Jesus, William B. Eerdmans Publishing House, Grand Rapids, MI.

Stiller, B.C., 2005, Preaching parables to postmoderns, Fortress Press, Minneapolis, MN. (Fortress Resources for Preaching).

Van Eck, E., 2007, 'The tenants in the vineyard (GThom 65/Mark 12:1-12): A realistic and social-scientific reading', HTS Teologiese Studies/ Theological Studies 63(3), 909-936. http://dx.doi.org/10.4102/hts.v63i3.233

Van Eck, E., 2011, 'When neighbours are not neighbours: A social-scientific reading of the parable of the friend at midnight (Lk 11:5-8)', HTS Teologiese Studies/Theological Studies 67(1), Art. \#788, 14. http://dx.doi.org/10.4102/hts. v67ilit.788.

Van Eck, E., 2013, 'When patrons are patrons: A social-scientific and realistic reading of the parable of the Feast (Lk 14:16b-23)', HTS Teologiese Studies/Theological Studies 69(1), Art. \#1375, 14. http://dx.doi.org/10.4102/hts.v69i1.1375

Via, D.O., 1967, The parables: Their literary and existential dimension, Fortress Press, Philadelphia, PA.

Wailes, S.L., 1987, Medieval allegories of Jesus' parables, University of California Press, Berkeley, CA.

Wallace-Hadrill, A., 1989, 'Patronage in Roman society: From Republic to Empire', in A. Wallace-Hadrill (ed.), Patronage in ancient society, pp. 63-87, Routledge, New York, NY.

Weder, H., 1984, Die Gleichnisse Jesu als Metaphern: Traditions- und redaktionsgeschichtliche Analysen und Interpretationen, Vandenhoeck \& Ruprecht, Göttingen. (Forschungen zur Religion und Literatur des Alten und Neuen Testaments, 120).

Wenham, D., 1989, The parables of Jesus: Pictures of a revolution, Hodder \& Stoughton, London. (The Jesus Library).

Zimmermann, R., 2007, 'Die Gleichnisse Jesu: Eine Leseanleitung zum Kompendium', in R. Zimmermann, D. Dormeyer, G. Kern, A. Merz, C. Münch \& E.E. Popkes (hrsg.) Kompendium der Gleichnisse Jesu, pp. 3-45, Gütersloher Verlagshaus, München. 